\title{
Passive Transfer of Sera from ALS Patients with Identified Mutations Evokes an Increased Synaptic Vesicle Number and Elevation of Calcium Levels in Motor Axon Terminals, Similar to Sera from Sporadic Patients
}

\author{
Valéria Meszlényi ${ }^{1,2}{ }^{2}$, Roland Patai ${ }^{1}{ }^{\circledR}$, Tamás F. Polgár ${ }^{1}$, Bernát Nógrádi ${ }^{1,2}{ }^{\circledR}$, Laura Körmöczy ${ }^{1}$, \\ Rebeka Kristóf ${ }^{1}$, Krisztina Spisák ${ }^{1}$, Kornélia Tripolszki ${ }^{3}$, Márta Széll ${ }^{3,4}$, Izabella Obál ${ }^{5,6}$, \\ József I. Engelhardt ${ }^{6}$ and László Siklós ${ }^{1, *}$ \\ 1 Biological Research Centre, Institute of Biophysics, 62 Temesvári krt., H-6726 Szeged, Hungary; \\ mesval13@gmail.com (V.M.); patai.roland@brc.hu (R.P.); polgar.tamas@brc.hu (T.F.P.); \\ bernatnogradi@gmail.com (B.N.); laura.kormoci96@gmail.com (L.K.); crebby32@gmail.com (R.K.); \\ spisakkrisztina96@gmail.com (K.S.) \\ 2 Foundation for the Future of Biomedical Sciences in Szeged, Szeged Scientists Academy, 15 Lechner tér, \\ H-6721 Szeged, Hungary \\ 3 Department of Medical Genetics, University of Szeged, 4/B Szőkefalvi-Nagy Béla u., H-6720 Szeged, \\ Hungary; tripolszki.kornelia@med.u-szeged.hu (K.T.); szell.marta@med.u-szeged.hu (M.S.) \\ 4 Dermatological Research Group, University of Szeged, Hungarian Academy of Sciences, 4/B \\ Szőkefalvi-Nagy Béla u., H-6720 Szeged, Hungary \\ 5 Department of Neurology, Aalborg University Hospital, 15 Skovvej Sdr., DK-9000 Aalborg, Denmark; \\ obalizabella@yahoo.com \\ 6 Department of Neurology, University of Szeged, 6 Semmelweis u., H-6725 Szeged, Hungary; \\ eji48dec9@yahoo.com \\ * Correspondence: siklos.laszlo@brc.hu; Tel.: +36-62-599-611
}

Received: 16 July 2020; Accepted: 31 July 2020; Published: 3 August 2020

Abstract: Previously, we demonstrated increased calcium levels and synaptic vesicle densities in the motor axon terminals (MATs) of sporadic amyotrophic lateral sclerosis (ALS) patients. Such alterations could be conferred to mice with an intraperitoneal injection of sera from these patients or with purified immunoglobulin G. Later, we confirmed the presence of similar alterations in the superoxide dismutase 1 G93A transgenic mouse strain model of familial ALS. These consistent observations suggested that calcium plays a central role in the pathomechanism of ALS. This may be further reinforced by completing a similar analytical study of the MATs of ALS patients with identified mutations. However, due to the low yield of muscle biopsy samples containing MATs, and the low incidence of ALS patients with the identified mutations, these examinations are not technically feasible. Alternatively, a passive transfer of sera from ALS patients with known mutations was used, and the MATs of the inoculated mice were tested for alterations in their calcium homeostasis and synaptic activity. Patients with 11 different ALS-related mutations participated in the study. Intraperitoneal injection of sera from these patients on two consecutive days resulted in elevated intracellular calcium levels and increased vesicle densities in the MATs of mice, which is comparable to the effect of the passive transfer from sporadic patients. Our results support the idea that the pathomechanism underlying the identical manifestation of the disease with or without identified mutations is based on a common final pathway, in which increasing calcium levels play a central role.

Keywords: ALS; passive transfer; intracellular calcium; synaptic vesicles; SOD1 mutation; C9ORF72 mutation 


\section{Introduction}

Amyotrophic lateral sclerosis (ALS) is one of the most common motor neuron diseases, which, according to the historical principles of neurology, primarily affects the upper and lower motor neurons [1]. ALS patients are traditionally sorted into two categories. Familial ALS patients represent $5-10 \%$ of the patient population, with more than a dozen, mostly autosomal dominant, mutations in different genes [2,3]. The sporadic form, with no familial accumulation, represents the overwhelming majority, i.e., 90-95\%, of ALS patients [4]. However, the identification of an expansion of the intronic hexanucleotide repeat sequence in chromosome nine open reading frame 72 (C9ORF72) in patients with no family history significantly contributed to the decline of the traditional distinction between sporadic and familial ALS, which have identical clinical manifestations [5]. Since the hexanucleotide repeat sequence in C9ORF72 is now considered the most frequent genetic alteration, not just in ALS but in frontotemporal dementia [6], ALS is now considered a multisystem disorder, overlapping mostly with frontotemporal dementia [7].

In addition, regarding disease manifestations on a continuum of frontotemporal dementia, ALS blurs the distinction between two specific neurodegenerative diseases. Another noteworthy observation is that the identified pathomechanisms of ALS are not restricted to this syndrome [8]. Indeed, mechanisms including, but not restricted to, excitotoxicity $[9,10]$, oxidative stress [11-13], mitochondrial dysfunction [14,15], immune/inflammatory reactions [16-18] and perturbed neuronal calcium homeostasis [19-23] are shown to contribute to the pathobiology of multiple sclerosis, Alzheimer's, Parkinson's, Huntington's, and other diseases as well.

ALS plays a distinguished role since, unlike other neurodegenerative diseases affecting the central nervous system, parts of the degenerating nerve cells can be sampled without the necessity of ethically questionable brain biopsies. This special anatomical feature [24] provides the opportunity to compare and validate the results obtained from animal models with appropriate human samples.

It is now accepted that the disturbed calcium homeostasis of affected neurons plays a general role in neurodegenerative diseases [19], and particularly in ALS, this mechanism may serve as a central factor, providing positive feedback between the individual components of the complex pathomechanism of the disease [25]. In our pioneering study with electron microscopic analyses, we described an elevated calcium level accompanied by an increased number of synaptic vesicles in the motor axon terminals obtained from sporadic ALS patients [26]. While these results documented for the first time the perturbed calcium homeostasis in degenerating human nerve cells, the applied sampling was not uniform, since it was restricted to a subpopulation of ALS patients with sporadic classifications and no identified mutations. To complete the study and generalize the results, an analysis of the muscle biopsy samples from patients with identified mutations was required.

Based on our human muscle biopsy study, motor axon terminals could be localized in only $10 \%$ of the 71 patients who underwent a routine biopsy of the biceps muscles in a period of 9 months [26]. In view of these numbers, and because of the low incidence of patients with familial history or identified mutations, similar examinations are not feasible, since according to the current epidemiological data [27], the worldwide prevalence of ALS is $4-8$ persons/100,000 inhabitants. Thus, such a study would require a group size of 10 million to provide the same number of patients with a familial history or identified mutations as in the sporadic study.

An indirect approach to disclose information about the underlying mechanisms in patients with ALS-related mutations relies on the passive transfer of their blood-derived samples to experimental animals. Indeed, anomalies, i.e., elevated calcium levels and increased numbers of synaptic vesicles, observed in the motor axon terminals of sporadic ALS patients, can be transferred to mice inoculated with whole serum or even with immunoglobulin $\mathrm{G}(\mathrm{IgG})$ purified from the blood of these patients [28]. If similar alterations are induced in the blood samples from patients with known mutations (mostly familial patients), assuming corresponding changes in the donor patients, a coherent view of the role of calcium in the pathomechanism of ALS could be confirmed. With the present demonstration that increased calcium can be transferred with the sera from ALS patients with identified mutations, 
data describing increased calcium in the axon terminals of sporadic ALS patients, increased calcium after passive transfer from sporadic patients and increased calcium in the genetic model of familial ALS could be obtained (Figure 1).

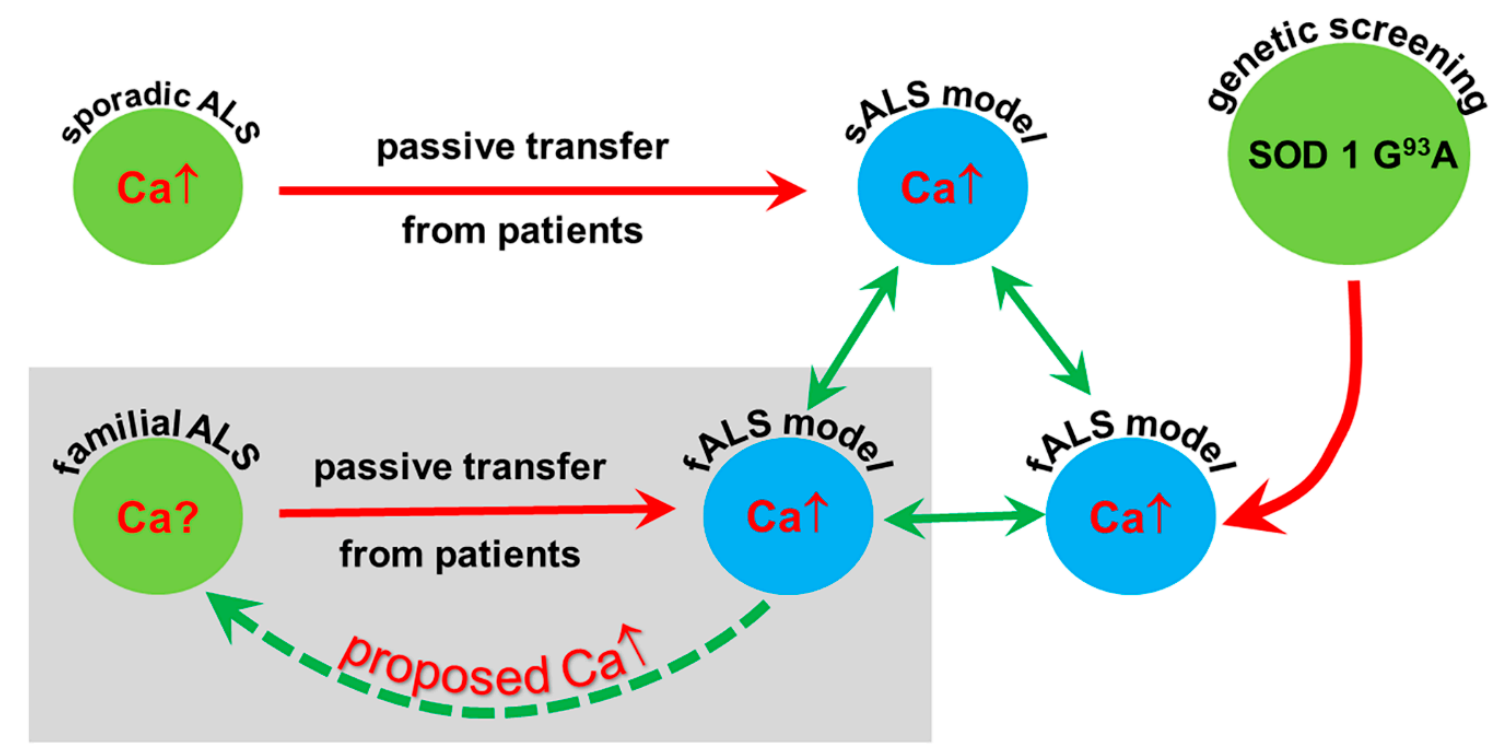

Figure 1. Amyotrophic lateral sclerosis (ALS) patients are represented with green circles, and the ALS models are symbolized with blue circles. With the passive transfer of serum or immunoglobulin G (IgG) from sporadic patients to mice (red arrow), a model of sporadic ALS could be created which reproduces the elevated calcium in the motor axon terminals demonstrated in the patients. ALS patients are represented with green circles, and the ALS models are symbolized with blue circles. A transgenic model of familial ALS, based on the mutations identified in patients, could also be created (curved red arrow). By replicating the sporadic ALS model with the passive transfer of sera from familial patients (shaded area), another model of familial ALS was set up in the present study. Since in each model comparable increases of calcium in the motor axon terminals could be demonstrated (green arrows), an elevated calcium level in the motor axon terminals, similar to that seen in sporadic patients, could be hypothesized for the familial ALS patients (dashed green arrow).

Twelve ALS patients with identified mutations, with or without family history (two patients had no family history or known mutations) were introduced to the study. Sera prepared from the patients were intraperitoneally injected into mice for 2 days with daily injections, then the motor axon terminals were analyzed electron microscopically to determine the calcium content and the number of synaptic vesicles. The observed increase in calcium levels and the elevated number of synaptic vesicles in the axon terminals, together with the previous observations of elevated calcium in the genetic model of familial ALS and the passive transfer model of sporadic ALS, provide additional data for the concept that elevated calcium levels play a central role in the pathomechanism of ALS. This common denominator may contribute to the identical clinical manifestation of the disease in its final stage.

\section{Results}

\subsection{Ultrastructural Alterations of the Motor Axon Terminals after Inoculation with ALS Sera}

The postsynaptic compartments of the neuromuscular synapses of mice inoculated with sera obtained from different ALS patients displayed no structural alterations: intact muscle fibers and specialized postsynaptic membranes were visible (Figure 2). Compared to the controls, the most obvious alterations of the motor axon terminals of mice injected with sera from ALS patients were the increased number of electron-dense deposits (EDDs), representing the distribution of calcium in the tissue, and the increased number of synaptic vesicles (Figures 2 and 3). Qualitatively, these changes were most 
prominent in the axon terminals of mice injected with sera from the patient with a C9ORF72 mutation (Figure 2D). Occasionally, swollen mitochondria containing clusters of EDDs were encountered in the axon terminals of the mice (Figure 2C).
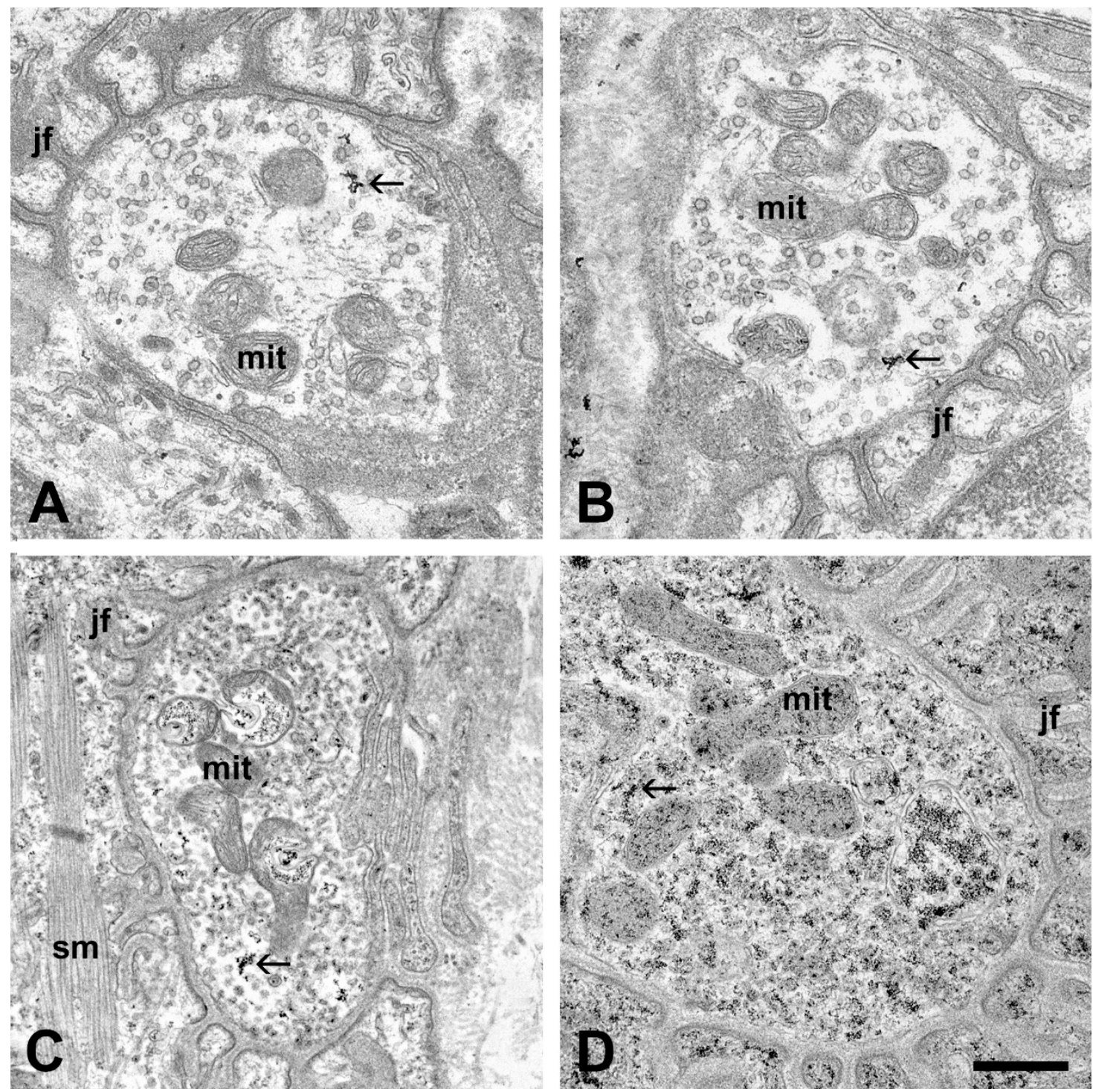

Figure 2. Electron micrographs of the neuromuscular synapses in the interosseous muscles after oxalate-pyroantimonate fixation. Junctional folds (jf) with no structural alterations are visible around all axon terminals. Axon terminals from an untreated mouse (A), and from a mouse injected with serum from a healthy individual (B) show no sign of structural damage, and contain intact mitochondria (mit). Furthermore, calcium-containing electron-dense deposits (EDDs) are only sparsely visible (arrows). Axon terminals from mice injected with sera from ALS patients, exemplified with superoxide dismutase 1 (SOD1) pAsp90Ala (C) and chromosome 9 open reading frame 72 (C9ORF72 (D)) mutations, display an increased amount of EDDs (arrows), particularly in (D). Furthermore, a global increase in synaptic vesicles can be noted. Occasionally, swollen mitochondria (mit) with clusters of EDDs are visible (C). sm: skeletal muscle. Scale bar: $500 \mathrm{~nm}$. 

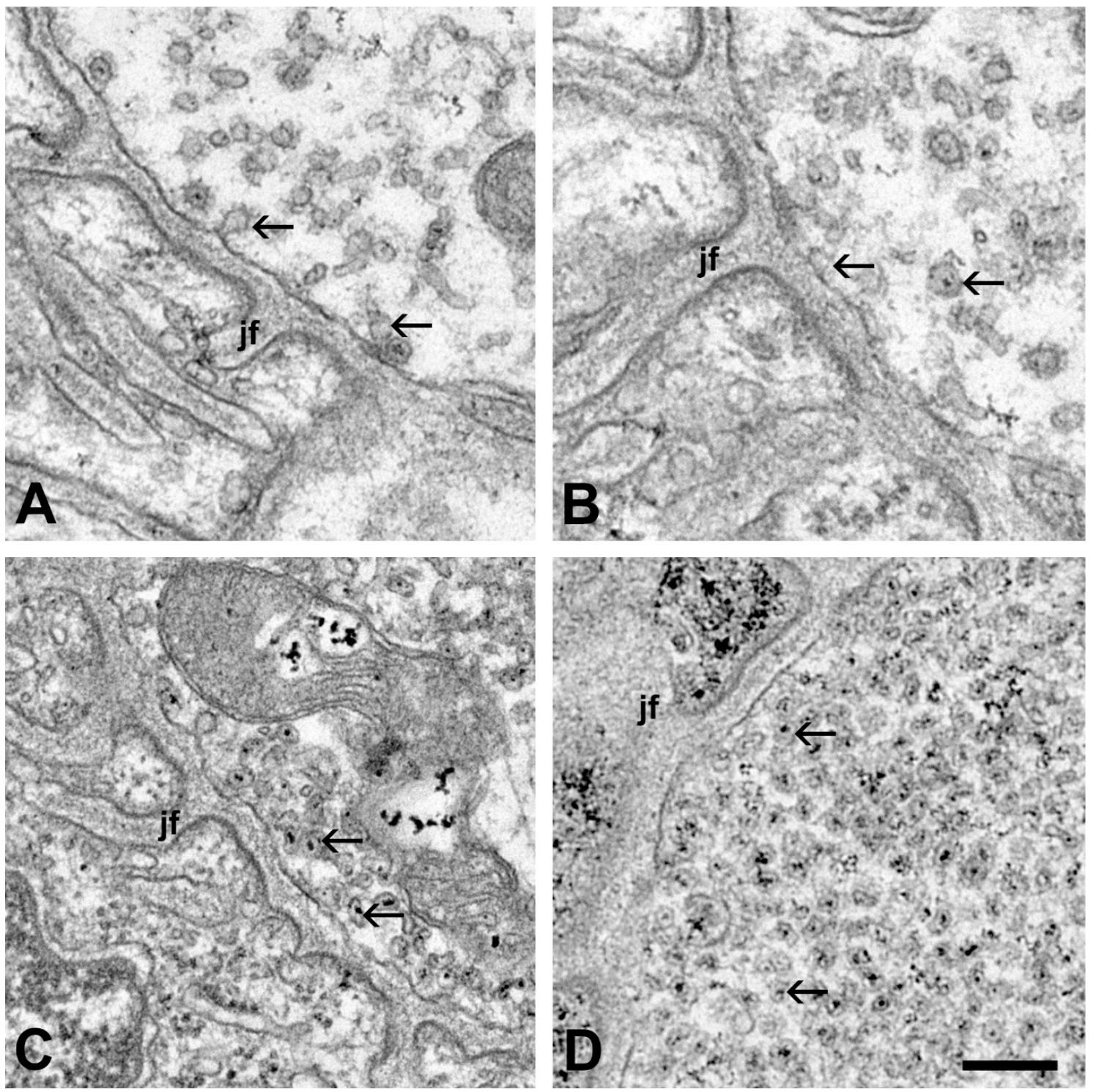

Figure 3. Enlarged view of motor axon terminals in the vicinity of the active zones of the neuromuscular synapses - oxalate-pyroantimonate fixation. In the axon terminal of an untreated mouse (A), and a mouse injected with serum from a healthy individual (B), only a few synaptic vesicles (arrows) are present. Some of them contain dot-like electron-dense deposits (EDDs). Axon terminals from mice injected with serum from ALS patients, represented with superoxide dismutase 1 (SOD1) pAsp90Ala (C) and chromosome 9 open reading frame 72 (C9ORF72) mutations (D), display an increased number of synaptic vesicles in these regions. The increase in the number of synaptic vesicles is exceptionally high in the axon terminal of a mouse injected with the sera from a patient with a C9ORF72 mutation (D). jf: junctional folds. Scale bar: $200 \mathrm{~nm}$.

2.2. Quantitative Analysis of the Change in the Number of Synaptic Vesicles and Increase in Intracellular Calcium in Motor Axon Terminals after an Inoculation with ALS Sera

The intracellular calcium level of motor axon terminals was expressed as the volume occupied by the EDDs relative to the volume of the axon terminal. Supporting the qualitative observations, an inoculation with all ALS sera induced a significant calcium increase in the axon terminals (superoxide dismutase 1 (SOD1) pLeu144Phe: $17.31 \% \pm 0.96 \%$; SOD1 pVal14Met: $17.67 \% \pm 1.96 \%$; SOD1 pAsp90Ala: 19.37\% \pm 1.78\%; SOD1 pLys91ArgfsTer8: $21.84 \% \pm 1.23 \%$; C9ORF72: $34.29 \% \pm$ 2.45\%; sequestosome 1 (SQSTM1) pPro392Leu: $17.30 \% \pm 3.41 \%$; G2/mitotic-specific cyclin F (CCNF) 
pLeu106Val: $21.06 \% \pm 3.68 \%$; NEK1 (NIMA-related kinase 1) and TBK1 (TANK-binding kinase 1): $20.47 \% \pm 3.19 \%$; UBQLN2 (Ubiquilin 2): $17.62 \% \pm 3.42 \%$; sporadic: $23.60 \% \pm 1.37 \%$ ) compared to the control groups (untreated: $5.42 \% \pm 0.68 \%$; healthy serum treated: $6.86 \% \pm 1.10 \%$ (Figure 4)).

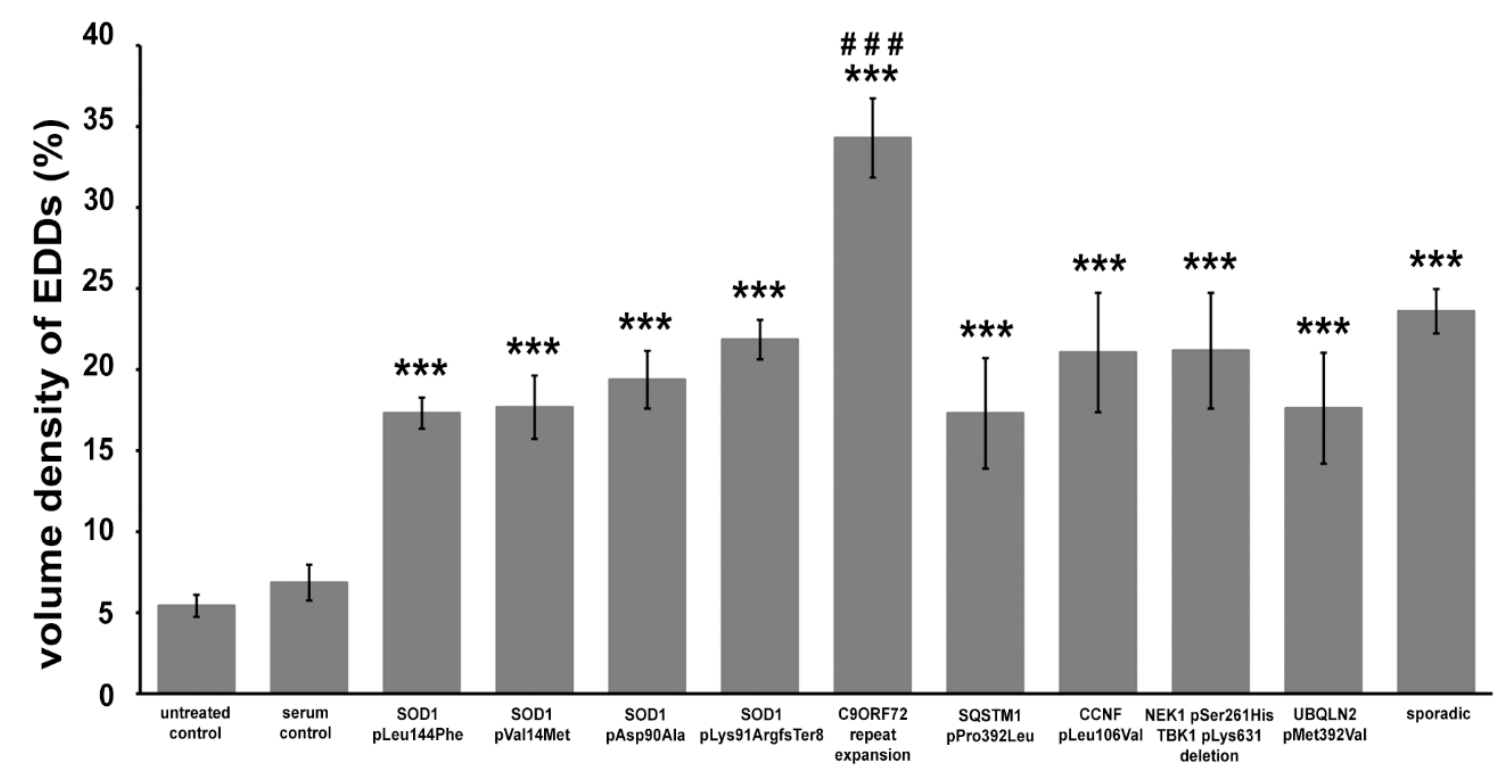

Figure 4. The ratio of the volume of electron-dense deposits (EDDs) and the volume of the axon terminals after inoculation with sera from ALS patients. A significant elevation in EDDs could be noted in each amyotrophic lateral sclerosis (ALS) serum treated group. Furthermore, this elevation was significantly higher (\#\#: $p<0.001$ ) in the motor axon terminals of mice injected with sera from ALS patients with C9ORF72 mutations compared to all other groups. Data are represented as the mean value \pm standard error of the mean (s.e.m.). Statistical evaluation was determined using a one-way analysis of the variance (ANOVA) with the least significant difference post-hoc pairwise comparison. $* * *: p<0.001$.

To reduce the variability of the results due to the largely inhomogeneous distribution of synaptic vesicles within the axon terminals, a quantitative evaluation of the density of synaptic vesicles was limited to the active zones, the physiologically most relevant regions of the synapses. All treatments with ALS sera resulted in significant increases in the synaptic vesicle density (SOD1 pLeu144Phe: $110.30 \pm 8.81$ vesicles $/ \mu \mathrm{m}^{3}$; SOD1 pVal14Met: $134.65 \pm 1.82$ vesicles $/ \mu \mathrm{m}^{3}$; SOD1 pAsp90Ala: $133.87 \pm 10.88$ vesicles $/ \mu^{3}{ }^{3}$; SOD1 pLys91ArgfsTer8: $120.28 \pm 11.26$ vesicles $/ \mu \mathrm{m}^{3}$; C9ORF72: $201.15 \pm 14.29$ vesicles/ $\mu^{3}{ }^{3}$; SQSTM1 pPro392Leu: $108.01 \pm 12.74$ vesicles $/ \mu^{3}{ }^{3}$; CCNF pLeu106Val: $124.60 \pm 9.91$ vesicles/ $\mu \mathrm{m}^{3}$; NEK1 and TBK1: $162.43 \pm 3.19$ vesicles/ $\mu \mathrm{m}^{3}$; UBQLN2: $138.55 \pm 15.02$ vesicles $/ \mu \mathrm{m}^{3}$; sporadic: $116.10 \pm 7.68$ vesicles $/ \mu \mathrm{m}^{3}$ ), while there were no significant changes in the group treated with healthy sera $\left(89.40 \pm 6.05\right.$ vesicles $\left./ \mu \mathrm{m}^{3}\right)$ compared to the control $\left(80.38 \pm 1.5\right.$ vesicles $/ \mu \mathrm{m}^{3}$ (Figure 5$)$ ).

The elevations in the density of the active zone synaptic vesicles and the level of intracellular calcium were noted as significant effects of the inoculation with sera from ALS patients. Since these parameters are closely associated with the activity of the synapses, their cross-relation was analyzed as well (Figure 6). In Figure 6, each point represents patients, except the "untreated control" points, which display values derived from individual mice, to illustrate the reproducibility of the histochemical method. The data points are split into three main groups: controls, ALS patients and ALS outliers, representing the patients with the C9ORF72 mutation. A K-means statistical cluster analysis confirmed the presence of these distinct clusters: (i) one represented the untreated mice and the healthy volunteers, (ii) another shows all ALS mutations, except the C9ORF72, (iii) and the last cluster represented the patients with a C9ORF72 mutation (Figure 6). 


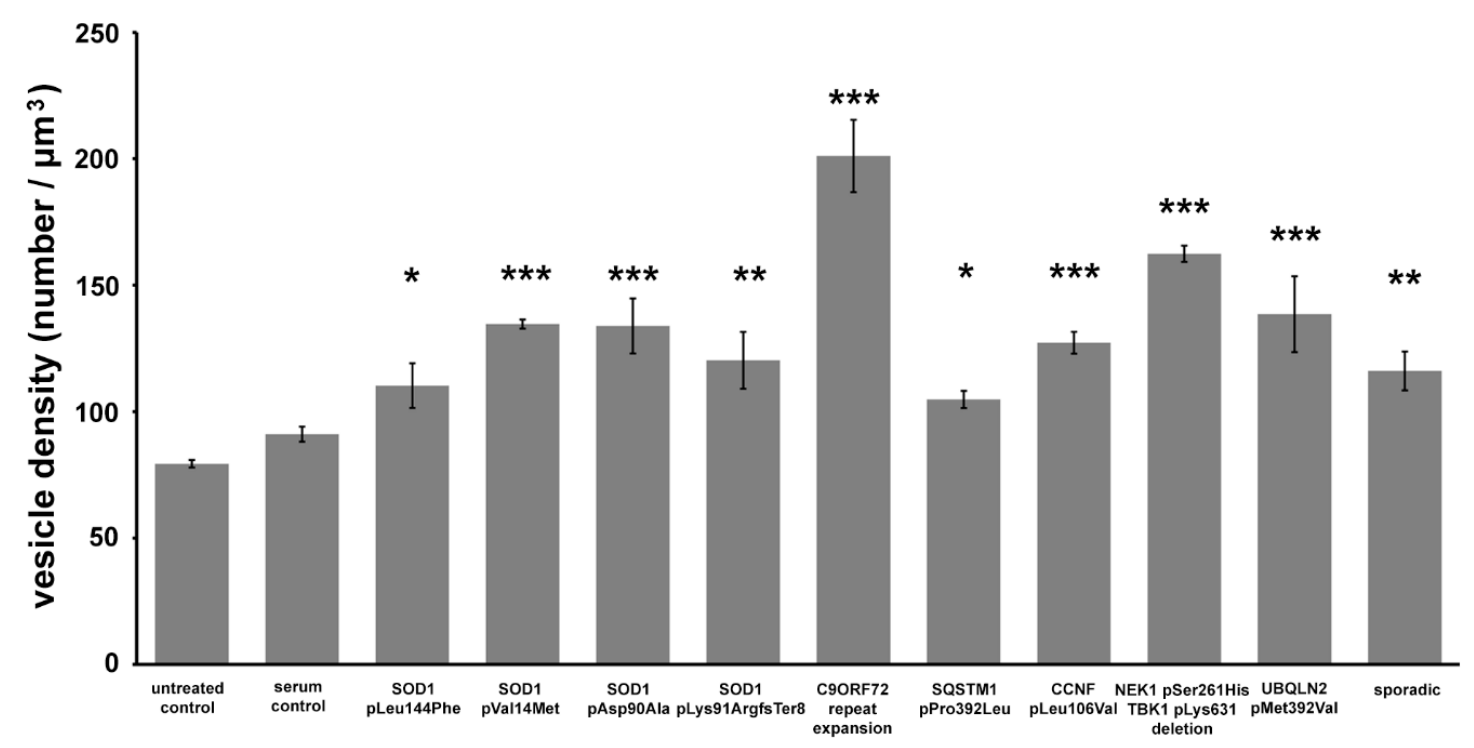

Figure 5. Volume density of synaptic vesicles in the active zones of neuromuscular synapses of mice inoculated with sera from amyotrophic lateral sclerosis (ALS) patients. All sera from ALS patients induced a significant increase in the number of active zone synaptic vesicles. Data are represented as the mean value \pm standard error of the mean (s.e.m.). Statistical evaluation was determined using a one-way analysis of the variance (ANOVA) with the least significant difference post-hoc pairwise comparison. *: $p<0.05 ;{ }^{* *}: p<0.01{ }^{* * *}: p<0.001$.

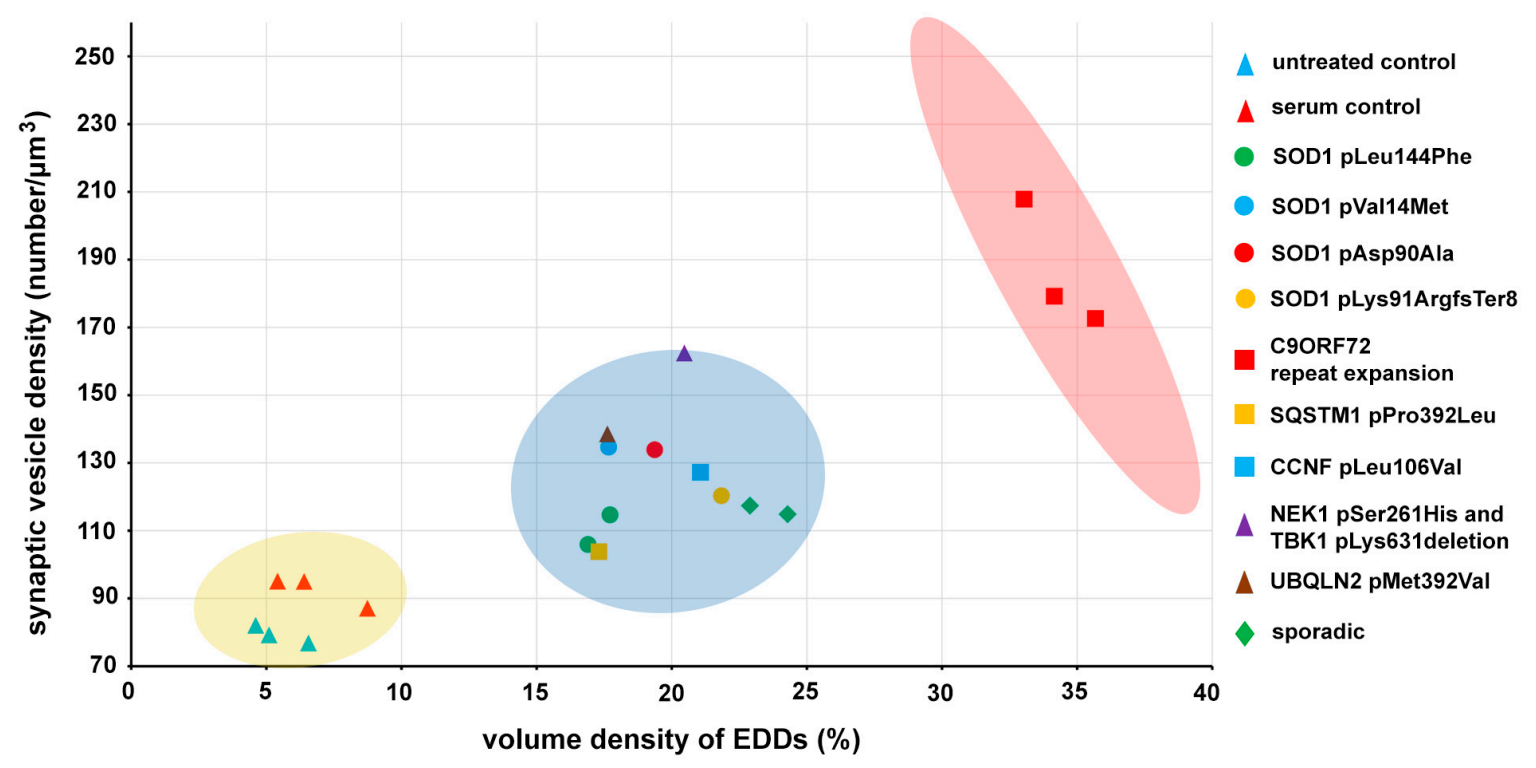

Figure 6. The active zone synaptic vesicle density is plotted against the volume density of the calcium-containing electron-dense deposits (EDDs). Since all amyotrophic lateral sclerosis (ALS) sera treatments resulted in a mutual increase in calcium levels and the density of synaptic vesicles, their combined values could form new groups (blue ellipse) separated from controls (yellow ellipse). The points representing the patients with the chromosome 9 open reading frame 72 (C9ORF72) mutation were sorted into a stand-alone cluster (represented by the red ellipse), and this group is beyond the 99.5\% confidence regions of the control and the ALS groups represented by the covered area of the yellow and blue confidence ellipses. 


\section{Discussion}

Calcium, a ubiquitous second messenger, plays an integral physiological role as summarized by Otto Loewi in his famous saying "Yes, calcium is everything" (1959). It has also been proposed to play a role in pathological situations [29]. However, starting from the early 1980s, based on the pioneering studies of Dennis W. Choi on neocortical cultures [30,31], an autonomous "calcium hypothesis" has been developed, since, according to his observations, the "toxicity of glutamate on cortical neurons may depend primarily on the presence of extracellular calcium, probably through a mechanism which is distinct from simple excitotoxicity" [32]. Nowadays it is widely accepted that increased calcium levels are a key factor not only in acute injuries $[10,33]$ but also in the pathobiology of neurodegenerative diseases [19,21,34-37].

The role of calcium in the pathomechanism of different neurodegenerative diseases has been directly or indirectly evidenced in their models, such as in Alzheimer's disease [38], Parkinson's disease [36], or ALS [39,40]. However, a direct demonstration of altered calcium levels in degenerating human nerve cells has been hampered due to the absence of brain biopsy samples for calcium studies, because of evident ethical concerns, and as autopsy samples are not suitable for this purpose since the fast diffusion of intracellular elements significantly alters their original distribution. ALS, however, is unique compared to other neurodegenerative diseases, since, due to the anatomy of the motor system, parts of the degenerating motor neurons residing in the skeletal muscles can be sampled with routine muscle biopsies [24].

In our original study, based on the results of muscle biopsies obtained from seven sporadic ALS patients, increased calcium levels and an increased synaptic vesicle number could be demonstrated in the motor axon terminals. These parameters separated the patients from the control population [26]. Similar alterations could be transferred to mice via inoculation of the total sera or IgG obtained from these patients $[17,28]$. In the present experiment, to prove that similar alterations may exist in the rest of the population of ALS patients, sera from ALS patients with identified mutations were collected, inoculated into mice, and the motor axon terminals in the hindlimb interosseous muscles were analyzed. For these experiments, instead of $\mathrm{IgG}$, serum was used for injections, as in our previous study [17], because it exhibits more complex and stronger biological effects than the isolated and thus partially inactivated IgG. The degenerative effect of ALS serum partially comes from the presence of autoimmune IgG antibodies, which were characterized in another study where a panel of 20 IgG antibodies specific for ALS were identified from the sera of ALS patients [41]. Furthermore, purified IgG can initiate motoneuronal calcium accumulation, as was demonstrated by Pullen and his coworkers $[42,43]$. ALS IgG also induced selective motor neuron apoptosis in rat mixed primary spinal cord cultures [44]. Immunoglobulins from patients with sporadic ALS can bind [45] and alter the function of L-type and P-type, as well as other neuronal calcium channels [46-49]. These antibodies induce ultrastructural degeneration in motor neurons and an increase in intracellular calcium [50], as well as an increase in the frequency of miniature endplate potentials [48] and glutamate levels in the cerebrospinal fluid [51]. The intraperitoneal administration of IgG from ALS patients and the immunized goat model of ALS increased TNF- $\alpha$, IL-6, and IL-10 levels in the spinal cord and the serum of inoculated mice [52]. The pathomechanistic role of ALS IgG in the sera of the patients seems to be essential since, if the IgG is removed by pre-incubating it with anti-human IgG or with the putative target of the antibodies, the pathobiological effects completely vanish [48]. Besides the effect on motor neurons, the various specific effects of ALS IgG were described in other cell types, also playing a role in the pathomechanism of ALS. These antibodies are capable of inducing oxidative stress and an upregulation of the antioxidative system in a BV-2 microglial cell line [53] and also affect cytosolic calcium homeostasis in cultured rat astrocytes [54]. Nevertheless, sera from two sporadic ALS patients were also included in the present study, which proved that identical results could be obtained from these patients as in the previous study. The present results, together with our earlier findings [26], provide the basis for the assumption that in ALS, regardless of the primary cause of the disease, calcium plays a central role in the pathomechanism. The increased number of synaptic 
vesicles and the simultaneously elevated levels of intra-terminal calcium are congruent with the needle electromyography findings in ALS patients with spontaneous and involuntary discharges, which may arise from the motoneuron or its axon [55]. In vitro, our findings are also compatible with the physiological abnormality of increased miniature endplate potentials, which are depolarizations of the postsynaptic terminal caused by the release of a single vesicle into the synaptic cleft, which could be induced by the passive transfer of IgG [56] or sera [57] from ALS patients.

The present findings demonstrate that, according to the mutual effect of the sera from ALS patients with known mutations on the number of synaptic vesicles and the level of intracellular calcium, the patients can be sorted into clusters that differentiate them from the controls (Figure 6). Although it lies beyond the scope of the present study to analyze the effect of the sera obtained from patients with different mutations, it is noteworthy that the effect of the sera obtained from patients with the C9ORF72 mutation exceeds the effect of all other sera from patients with identified mutations (Figure 6). The extraordinary effect of this mutation might be attributed to both the loss of function of the C9ORF72 protein and toxic gain of function from the C9ORF72 repeat ribonucleic acid (RNA), or from dipeptide repeat proteins produced by a repeat-associated non-ATG translation [58]. Mutations in this gene have a strong immune/inflammatory effect due to a generalized systemic pro-inflammatory state, which initiates autoimmunity-related degenerative pathways and microglia activation in the C9ORF72 knock-out model of ALS [59], without a regression of the motor function [60].

In summary, it should be noted that starting from the original observation that calcium is indeed elevated in the degenerating nerve cells of humans [26], which can be replicated in different models of ALS [28,61], several lines of study have been initiated, investigating this pathobiological process as a possible neuroprotective strategy in ALS. For example, based on the recognition that certain calcium-binding proteins may lend resistance to neurons [62-64], double transgenic parvalbumin $\times$ mutant SOD1 mice were bred, overexpressing the parvalbumin protein in spinal motor neurons, which delayed disease onset in the mice, but could not ultimately rescue them [65]. It was a reasonable assumption that increasing the calcium buffering capacity of the cells would increase their tolerance, but, per definition, sooner or later saturation occurs if the stress endures. However, an alternative therapeutic approach was based on reducing the calcium influx through calcium-permeable $\alpha$-amino-3-hydroxy-5-methyl-4-isoxazole propionic acid (AMPA) receptors, which has a specific alteration in ALS [66]. After some promising results in SOD1 transgenic mice with the drug Talampanel [67], which was also introduced in clinical trials, it turned out, that its protective effect against calcium overload was effective only if the treatment was started before the appearance of clinical symptoms [68]. Our present results confirm the central role of calcium in the pathomechanism of ALS and probably in other neurodegenerative diseases. This phenomenon may unify the different pathomechanisms into a self-perpetuating cascade [25] responsible for the identical clinical manifestation of different forms of ALS, regardless of whether the patients possess mutations for the disease, which underlines the necessity of early diagnostic markers for effective treatments.

\section{Materials and Methods}

\subsection{Ethics Approval and Consent to Participate}

Ethical approvals for the studies involving animals were given by (1) The Government Office in Csongrád-Csanád County, Hungary; (2) The Committee for Animal Experiments of the University of Szeged, Szeged, Hungary I. 74-II/2015 (14 January 2015). All experiments were carried out in accordance with the institutional guidelines for the use and care of experimental animals and the governmental law for animal protection (XXVIII. chapter IV. paragraph 31) which conforms to international laws and policies (EEC Council Directive 86/609, OJL 3581 DEC. 12, 1987; NIH Guide for the Care and Use of Laboratory Animals, United States National Research Council, revised 1996). All efforts were made to minimize animal suffering throughout the experiments. 
Ethical approval for obtaining blood from patients and controls, for research purposes, and storing it anonymously with the written informed consent of patients and controls was given by The Human Investigation Review Board, University of Szeged, Hungary, in agreement with the declaration of the Medical World Federation proclaimed in Helsinki 1964. (Project title: Search for Biomarkers in Neurodegenerative Diseases: Amyotrophic Lateral Sclerosis, Parkinson's Disease and Alzheimer's Disease \#2557/2009 (29 June 2009, revised 23 January 2012).

\subsection{Patients}

Fourteen ALS patients (Table 1) and three healthy controls participated with informed consent in the study. Five ALS patients possessed mutations in the SOD1 gene. Three patients had a GGGGCC hexanucleotide repeat expansion in the C9ORF72 gene. One patient had a mutation in the SQSTM1 gene, another one had a mutation in the CCNF gene, a further one had a mutation in the UBQLN2 gene and finally, a patient with ALS and frontotemporal dementia had a double mutation in the NEK1 gene together with a mutation in the TBK1 gene (Table 1). Two patients, composing the sporadic ALS group, were genetically screened for all 35 major ALS genes and proved to be negative (Table 1). For controls, sera from 3 age-matched healthy volunteers were obtained. Untreated animals also served as controls.

The genomic DNAs were isolated from blood samples. The entire coding region of the SOD1 genes and the flanking introns were amplified and the polymerase chain reaction products underwent a direct sequencing on an ABI 3100 sequencer (Thermo Scientific; Waltham, MA, USA) and were compared with the wild-type sequences on the Ensemble Genome Browser [69]. The patients who carried the GGGGCC repeat expansion were also screened for the "risk" haplotype, the rs3849942 variant, which was used as a marker for the "risk" haplotype for the patient and control genotypes. Rs3849942 genotyping was based on allelic discrimination assays using TaqMan chemistry (Life Technologies; Budapest, Hungary) [69]. In patient mfALS 4 in Table 1, the mutation screening revealed a mutation located in the signal peptide (M24I) together with the SOD1 pLeu144Phe mutations. Patient mALS 9 with an SQSTM1 mutation, patient mALS 10 with a CCNF mutation, patient mALS 11 with a UBQLN2 mutation, and patient mALS 12 with a NEK1 mutation, together with TBK1 mutations, were evaluated. ALS patients screened for 35 major ALS related genes with known mutations were targeted in next-generation sequencing posteriorly [17].

The diagnoses fulfilled the El Escorial revisited [55] and the Awaji [70] criteria for ALS. The patients were followed up several times and their disease progressions were recorded with the revised ALS functional rating scale (ALSFRS-R) [71]. The blood samples taken from the cubital veins were frozen, partly as whole blood and partly as sera after centrifugation, and stored until use at $-80^{\circ} \mathrm{C}$. Only patient mALS12 had frontotemporal dementia. The scores of the Mini-Mental State Examination (MMSE) were in the normal range, except patient mALS 12 who had progressive frontotemporal dementia (Table 1). Initial symptoms in four patients with SOD1 mutations appeared as lower extremity weaknesses. In the fifth one, the initial symptoms involved all of the extremities. The disease in patient mALS 2 had progressed over 12 years with the mutation of SOD1 pAsp90Ala. The patient with the fast progression (6 months) had a novel heterozygous mutation (c.275_276delAA, pLys91ArgfsTer8) located in the fourth exon of the SOD1 gene and led to a frameshift with the insertion of 8 novel amino acids and the formation of a premature stop codon at the new amino acid position 99. Patient mALS 1 had a SOD1 mutation together with an angiogenin (ANG) mutation and lived one year after the onset of symptoms. Patient mfALS 3 and mfALS 4 survived for 2 years and 3 years after the appearance of the symptoms, respectively. The patients with a C9ORF72 repeat expansion had a short disease course initiated with bulbar (6, 8 and 12 months). The remaining four patients with genetic alterations also had a short (6 months) disease course. The two sporadic ALS cases without genetic alterations in the major ALS genes survived 9 months and 1 year after the diagnosis was established. 
Table 1. Summary of the clinical data of the patients.

\begin{tabular}{|c|c|c|c|c|c|c|c|c|c|c|}
\hline Patients & $\begin{array}{l}\text { Age at } \\
\text { Onset } \\
\text { (Years) }\end{array}$ & $\begin{array}{l}\text { Duration of } \\
\text { the Disease } \\
\text { at the Study }\end{array}$ & Initial Symptoms & $\begin{array}{l}\text { Clinical } \\
\text { Signs }\end{array}$ & ALS FRS-R & MMSE & Genetic Alteration & $\begin{array}{l}\text { Family } \\
\text { History }\end{array}$ & Therapy & Other Disease \\
\hline mALS 1 & 63 & 1 year & $\begin{array}{l}\text { proximal bilateral lower } \\
\text { limb weakness }\end{array}$ & LMN, UMN & $32 / 48$ & $28 / 30$ & $\begin{array}{l}\text { SOD1 pVal14 Met } \\
\text { ANG Met24lle }\end{array}$ & negative & $\begin{array}{c}\text { Riluzole, Perindopril, } \\
\text { Aspirin, Piracetam, } \\
\text { Vinpocetine, Nebivolol }\end{array}$ & atherosclerosis, hypertension \\
\hline mALS 2 & 75 & 12 years & $\begin{array}{l}\text { bilateral lower limb } \\
\text { weakness }\end{array}$ & $\begin{array}{l}\text { LMN, UMN, } \\
\text { B }\end{array}$ & $19 / 48$ & $29 / 30$ & SOD1 pAsp90Ala & negative & Riluzole & $\begin{array}{l}\text { cervical and lumbar } \\
\text { spondylarthrosis, } \\
\text { hyperlipidemia }\end{array}$ \\
\hline mfALS 3 & 29 & 2 years & gait disturbance & LMN, UMN & $36 / 48$ & $30 / 30$ & SOD1 pLeu144Phe & $\begin{array}{l}\text { grandmother } \\
\text { (fraternal) }\end{array}$ & Riluzole & - \\
\hline mfALS 4 & 49 & 3 years & $\begin{array}{l}\text { distal weakness of lower } \\
\text { limbs }\end{array}$ & $\begin{array}{l}\text { LMN, UMN, } \\
\text { B, PB }\end{array}$ & $25 / 48$ & $28 / 30$ & SOD1 pLeu144Phe & $\begin{array}{l}\text { grandmother } \\
\text { (maternal) }\end{array}$ & Riluzole, Citalopram & $\begin{array}{l}\text { depression, lumbar discs' } \\
\text { herniation }\end{array}$ \\
\hline mALS 5 & 67 & 6 months & four limbs weakness & $\begin{array}{l}\text { B, PB, UMN, } \\
\text { LMN }\end{array}$ & $39 / 48$ & $30 / 30$ & $\begin{array}{l}\text { SOD1 pLys91Arg fs } \\
\text { Ter8 }\end{array}$ & negative & $\begin{array}{l}\text { Riluzole, Atorvastatin, } \\
\text { Valsartan }\end{array}$ & $\begin{array}{c}\text { breast cancer (irradiated } 8 \\
\text { years ago), } \\
\text { hypercholesterolemia, cervical } \\
\text { and lumbar discs' protrusion }\end{array}$ \\
\hline mALS 6 & 68 & 6 months & $\begin{array}{l}\text { bilateral peroneal palsy, } \\
\text { dysarthria }\end{array}$ & $\begin{array}{l}\text { LMN, B, } \\
\text { UMN }\end{array}$ & $44 / 48$ & $30 / 30$ & $\begin{array}{l}\text { C9ORF72 repeat } \\
\text { expansion }\end{array}$ & negative & $\begin{array}{l}\text { Alprazolam, } \\
\text { Perindopril, Duloxetine }\end{array}$ & $\begin{array}{c}\text { hyperparathyroidism (cured), } \\
\text { generalized lipomatosis, } \\
\text { osteoporosis, hypertension, } \\
\text { depression }\end{array}$ \\
\hline mALS 7 & 55 & 1 year & dysarthria, dysphagia & $\begin{array}{l}\text { B, PB, LMN, } \\
\text { UMN }\end{array}$ & $37 / 48$ & $27 / 30$ & $\begin{array}{l}\text { C9ORF72 repeat } \\
\text { expansion }\end{array}$ & negative & Riluzole, L-thyroxin & Hashimoto's thyroiditis \\
\hline mfALS 8 & 56 & 8 months & dysarthria, dysphagia & $\begin{array}{l}\text { B, PB, LMN, } \\
\text { UMN }\end{array}$ & $36 / 48$ & $30 / 30$ & $\begin{array}{l}\text { C9ORF72 repeat } \\
\text { expansion }\end{array}$ & $\begin{array}{l}\text { mother with } \\
\text { suspected } \\
\text { ALS (not } \\
\text { documented) }\end{array}$ & Riluzole, L-thyroxin & hypothyroidism \\
\hline mALS 9 & 54 & 6 months & dyspnea & $\begin{array}{l}\text { B, PB, LMN, } \\
\text { UMN }\end{array}$ & $40 / 48$ & $30 / 30$ & SQSTM1 pPro392Leu & negative & Valsartan-HCT & hypertension \\
\hline mALS 10 & 61 & 6 months & $\begin{array}{l}\text { UMN, LMN lesions in the } \\
\text { lower limbs }\end{array}$ & $\begin{array}{c}\text { LMN, UMN, } \\
\text { B }\end{array}$ & $42 / 48$ & $30 / 30$ & CCNF pLeu106Val & negative & Valsartan, Riluzole & $\begin{array}{l}\text { hypertension, cervical and } \\
\text { lumbar discs' protrusion }\end{array}$ \\
\hline mALS 11 & 65 & 6 months & four limbs weakness & LMN, UMN & $43 / 48$ & $29 / 30$ & UBQLN2 pMet392Val & negative & Riluzole & hypertension depression \\
\hline mALS 12 & 37 & 6 months & $\begin{array}{c}\text { four limbs weakness, } \\
\text { dysarthria, cognitive deficit }\end{array}$ & $\begin{array}{l}\text { UMN, LMN, } \\
\text { B, PB }\end{array}$ & $39 / 48$ & $23 / 30$ & $\begin{array}{l}\text { NEK1 pSer261His TBK1 } \\
\text { pLys631 deletion }\end{array}$ & negative & $\begin{array}{l}\text { Riluzole, Perindopril, } \\
\text { Paroxetine }\end{array}$ & $\begin{array}{l}\text { hypertension depression, } \\
\text { frontotemporal dementia }\end{array}$ \\
\hline sALS1 & 71 & 1 year & $\begin{array}{l}\text { weakness of the right arm } \\
\text { and leg (peroneal) }\end{array}$ & UMN, LMN & $41 / 48$ & $28 / 30$ & - & negative & $\begin{array}{c}\text { Piracetam, Diclofenac, } \\
\text { Aspirin, Perindopril, } \\
\text { Isosorbide-mononitrate, } \\
\text { Bisoprolol } \\
\end{array}$ & $\begin{array}{c}\text { hypertension, } \\
\text { hypercholesterolemia, } \\
\text { atherosclerosis, post zoster } \\
\text { neuralgia }\end{array}$ \\
\hline sALS2 & 74 & 9 months & dysarthria, dysphagia & $\begin{array}{l}\text { B, UMN, } \\
\text { LMN }\end{array}$ & $39 / 48$ & $26 / 26$ & - & negative & $\begin{array}{c}\text { Amlodipine, } \\
\text { Perindopril, Metoprolol, } \\
\text { Atorvastatin, Riluzole }\end{array}$ & $\begin{array}{c}\text { hypertension, } \\
\text { hypercholesterolemia }\end{array}$ \\
\hline
\end{tabular}

mALS: ALS with identified mutation; mfALS: familial ALS with identified mutation; sALS: sporadic ALS; LMN: lower motor neuron; UMN: upper motor neuron; B: bulbar; PB: pseudobulbar; ALSFRS-R: ALS functional rating scale revised; MMSE: Mini-Mental State Examination. 


\subsection{Passive Transfer with Human Sera and Tissue Preparation}

Altogether, 48 male Balb/c mice, obtained from Charles River Appoints AnimaLab Hungary Kft. (Vác, Hungary), were injected intraperitoneally with $1 \mathrm{~mL} /$ day serum from ALS patients with different mutations $(n=3)$ or healthy serum $(n=3)$ for two days. All animals received sera from the same patient during the inoculation period. However, animals treated with serum from different patients with the same mutation (patients mfALS 3 and 4; patient mALS 6, 7 and 8) were pooled together, since there was no statistical difference between the effect of the sera from different patients with the same mutation. A similar pooling protocol was applied to animals treated with sera from sporadic patients (patient sALS 1,2). One group of animals did not receive an injection and was used as the untreated control $(n=3)$.

During the two-day inoculation period, animals were housed in plastic cages (5 animals/cage, at most) in a thermoneutral environment $\left(22 \pm 3{ }^{\circ} \mathrm{C}\right)$ and $12 \mathrm{~h}$ light/dark cycle with access to drinking water and regular rodent chow ad libitum. Twenty-four hours after the second serum injection, muscle samples from animals were prepared from the animals for the analytical study of calcium by an electron microscope, as described originally by Borgers and coworkers [72,73]. The method, as adapted and regularly tested for the specificity of calcium in our laboratory, ensures a good preservation of the tissue suitable for electron microscopy and results in the EDDs due to the precipitation of tissue calcium by the fixative [74-78].

First, animals under terminal anesthesia (avertin; 2,2,2-tribromoethanol, Merck, Darmstadt, Germany; $240 \mathrm{mg} / \mathrm{kg}$ body weight in a $1.0 \mathrm{~mL}$ volume i.p.) were transcardially perfused with $90 \mathrm{mM}$ potassium oxalate (Merck; $\mathrm{pH}$ adjusted to 7.4 with $\mathrm{KOH}$ ) followed by $3 \%$ glutaraldehyde (Polysciences Inc., Warrington, PA, USA; $\mathrm{pH}$ adjusted to 7.4 with $\mathrm{KOH}$ ) containing $90 \mathrm{mM}$ of potassium oxalate ( $\mathrm{pH}$ 7.4). The hindlimb interosseus muscles were removed and fixed in the same fixative overnight $\left(4{ }^{\circ} \mathrm{C}\right)$. Specimens were then rinsed in $7.5 \%$ sucrose (Molar Chemicals Kft., Budapest, Hungary) containing $90 \mathrm{mM}$ of potassium oxalate ( $\mathrm{pH} 7.4$ ), postfixed with $2 \%$ potassium pyroantimonate (Merck) $+1 \%$ osmic acid (Sigma; $\mathrm{pH}$ adjusted to 7.4 with acetic acid (Molar Chemicals Kft.)) for $2 \mathrm{~h}\left(4^{\circ} \mathrm{C}\right.$ ). Next, specimens were rinsed in distilled water ( $\mathrm{pH}$ adjusted to 10 with $\mathrm{KOH}$ ) for 10 min, dehydrated in a graded series of ethanol (Molar Chemicals Kft.), processed through propylene oxide (Merck), and embedded in Durcupan ACM (Merck). Blocks were polymerized for $48 \mathrm{~h}$ at $56^{\circ} \mathrm{C}$. Semithin $(0.3 \mu \mathrm{m})$ sections were cut from the blocks on an Ultracut UCT ultramicrotome (Leica, Wetzlar, Germany), etched [79] and stained [80], and then evaluated under an Eclipse 80i light microscope (Nikon, Tokyo, Japan) to identify the zones of innervation in the muscles. After trimming the blocks to the appropriate regions, to avoid personal bias in determining the fields for analysis [81], systematic random sets of ultrathin sections $(50 \mathrm{~nm}$ ) were prepared. The distance between the sections was set to $15 \mu \mathrm{m}$ to circumvent repeated sampling of identical neuromuscular synapses during the collection of electron microscopic images. Sections were mounted on single-hole formvar coated copper grids (Electron Microscopy Sciences, Hatfield, PA, USA), contrasted with uranyl acetate (Electron Microscopy Sciences; $2 \%$ in 50\% ethanol) [82] and lead citrate (Electron Microscopy Sciences; $2 \%$ in distilled water) [83].

\subsection{Quantification of the Intracellular Calcium Levels in the Motor Axon Terminals}

Ultrathin sections were examined using a JEM-1400Flash transmission electron microscope (JEOL, Tokyo, Japan). Sections from each animal were systematically screened at low magnification (500-2000×) for the presence of neuromuscular synapses until 15 axon terminals could be collected for microscopic analysis. Axon terminals were recorded as 16-bit grayscale images at an instrumental magnification of $12,000 \times$ with a $2 \mathrm{k} \times 2 \mathrm{k}$ high-sensitivity scientific complementary metal-oxide-semiconductor camera (Matataki Flash sCMOS, JEOL) and saved in a tagged image file format. The relative volume of the axon terminals occupied by the EDDs representing the calcium precipitates was determined by point counting methods $[84,85]$, which were modified for these unique structures and photographic conditions [75]. The recorded pictures were analyzed with the built-in modules of Image-Pro Plus (Media Cybernetics; Rockville, MD, USA) image analysis software. The tessellation of sampling 
points was superimposed onto each electron microscopic image, then sampling points hitting the axon terminals in each image served as reference areas and were counted. Sampling points hitting the EDDs within the reference area were counted as well. The corresponding counts obtained in the individual fields were summed up throughout the series of the identified axon terminals in each animal [86]. The appropriate ratios expressing the relative amount of the EDDs within these structures were calculated for each animal.

\subsection{Quantification of the Density of Synaptic Vesicles}

In addition to the calcium content in the axon terminals, changes in the synaptic vesicle density in the active zones were also analyzed and were expressed quantitatively. Electron microscopic images of 15 axon terminals were evaluated for each animal, where all active zones of the neuromuscular junction were quantified individually. Although the determination of the active zones for these measurements was arbitrary — by the symmetrical adjustment of a $100 \mathrm{~nm}$ wide and $200 \mathrm{~nm}$ long rectangle for the postsynaptic junction - this method was consistently applied during quantification, and adapted from the analysis of the human motor axon terminals [26]. The volume of the examined region was calculated using the area of the selected rectangle and the known section thickness. Subsequently, the number of synaptic vesicles was determined in the created cuboid. Synaptic vesicles were measured if their center was within the examined volume. Results were averaged per animal, then group averages were calculated using the individual values of the animals, which were expressed as volume densities.

\subsection{Statistical Analysis}

To determine the average volume occupied by EDDs within the axon terminals, and the synaptic vesicle density, the data derived from individual electron microscopic fields were pooled according to animals and passive transfer groups. Fifteen fields of view for each were analyzed in the motor axon terminals from each animal. Differences among the multiple means of the volume density of the EDDs were assessed by a one-way analysis of variance (ANOVA), followed by the least significant difference post-hoc test. All of the statistical analyses were performed with $\mathrm{R}$ (version 3.6.2, R Foundation for Statistical Computing, Vienna, Austria) and with R Studio Integrated Development Environment (version 1.1.453, RStudio Inc., Boston, MA, USA) for Windows. All data are presented as mean values \pm the standard error of the means (s.e.m.). A cluster analysis was performed using the K-means clustering algorithm with WEKA data mining software (v3.8.3., Waikato, New Zealand) to investigate the cross-relationship of the volume density of EDDs and synaptic vesicles in patients with different ALS genotypes and controls. Since the analysis resulted in distinct clusters, the Jaccard similarity index was not calculated, but the $99.5 \%$ confidence regions of the control and ALS groups were evaluated and represented in Figure 6 as confidence ellipses.

Author Contributions: Conceptualization, J.I.E. and L.S.; Data curation, R.P., T.F.P. and B.N.; Formal analysis, R.P., T.F.P. and K.T.; Funding acquisition, L.S.; Investigation, V.M., T.F.P., B.N., L.K., R.K., K.S., K.T. and I.O.; Methodology, R.P., M.S. and L.S.; Project administration, R.P., M.S. and J.I.E.; Resources, R.P.; Supervision, L.S.; Validation, M.S., J.I.E. and L.S.; Visualization, V.M., L.K., R.K. and K.S.; Writing一original draft, V.M. and R.P.; Writing-review and editing, J.I.E. and L.S. All authors have read and agreed to the published version of the manuscript.

Funding: This work was partially supported by the National Research, Development and Innovation Office of Hungary through the GINOP-2.3.2-15-2016-00001, GINOP-2.3.2-15-2016-00034 and GINOP-2.3.3.-15-2016-00001 programs. This research work was conducted with the support of the Szeged Scientists Academy under the sponsorship of the Hungarian Ministry of Human Capacities (EMMI: 11136-2/2019/FIRFIN). R.P. was supported by the "National Talent Programme" with the financial aid of the Ministry of Human Capacities (NTP-NFTÖ-18-B-208).

Acknowledgments: We thank Erika Bánfiné Rácz for her assistance in ultramicrotomy, and Jennifer Tusz to correcting the English language of the manuscript.

Conflicts of Interest: The authors declare no conflict of interest. 


\section{Abbreviations}

$\begin{array}{ll}\text { ALS } & \text { Amyotrophic lateral sclerosis } \\ \text { ALSFRS-R } & \text { Revised amyotrophic lateral sclerosis functional rating scale } \\ \text { AMPA } & \alpha \text {-amino-3-hydroxy-5-methyl-4-isoxazole propionic acid } \\ \text { ANG } & \text { Angiogenin } \\ \text { ANOVA } & \text { Analysis of variance } \\ \text { B } & \text { Bulbar } \\ \text { C9ORF72 } & \text { Chromosome } 9 \text { open reading frame 72 } \\ \text { CCNF } & \text { G2/mitotic-specific cyclin F } \\ \text { EDDs } & \text { Electron-dense deposits } \\ \text { IgG } & \text { Immunoglobulin G } \\ \text { LMN } & \text { Lower motor neuron } \\ \text { mALS } & \text { Amyotrophic lateral sclerosis with an identified mutation } \\ \text { mfALS } & \text { Familial amyotrophic lateral sclerosis with an identified mutation } \\ \text { MMSE } & \text { Mini-Mental State Examination } \\ \text { NEK1 } & \text { NIMA-related kinase 1 } \\ \text { PB } & \text { Pseudobulbar } \\ \text { RNA } & \text { Ribonucleic acid } \\ \text { sALS } & \text { Sporadic amyotrophic lateral sclerosis } \\ \text { s.e.m. } & \text { Standard error of the mean } \\ \text { SOD1 } & \text { Superoxide dismutase 1 } \\ \text { SQSTM1 } & \text { Sequestosome 1 } \\ \text { TBK1 } & \text { TANK-binding kinase 1 } \\ \text { UBQLN2 } & \text { Ubiquilin 2 } \\ \text { UMN } & \text { Upper motor neuron } \\ \end{array}$

\section{References}

1. Rowland, L.P.; Shneider, N.A. Amyotrophic lateral sclerosis. N. Eng. J. Med. 2001, 344, 1688-1700. [CrossRef] [PubMed]

2. Barber, S.C.; Shaw, P.J. Oxidative stress in ALS: Key role in motor neuron injury and therapeutic target. Free Radic. Biol. Med. 2010, 48, 629-641. [CrossRef] [PubMed]

3. Kurland, L.T.; Mulder, D.W. Epidemiologic investigations of amyotrophic lateral sclerosis. 2. Familial aggregations indicative of dominant inheritance. II. Neurology 1955, 5, 249-268. [CrossRef] [PubMed]

4. Kiernan, M.C.; Vucic, S.; Cheah, B.C.; Turner, M.R.; Eisen, A.; Hardiman, O.; Burrell, J.R.; Zoing, M.C. Amyotrophic lateral sclerosis. Lancet 2011, 377, 942-955. [CrossRef]

5. Turner, M.R.; Hardiman, O.; Benatar, M.; Brooks, B.R.; Chio, A.; de Carvalho, M.; Ince, P.G.; Lin, C.; Miller, R.G.; Mitsumoto, H.; et al. Controversies and priorities in amyotrophic lateral sclerosis. Lancet Neurol. 2013, 12, 310-322. [CrossRef]

6. DeJesus-Hernandez, M.; Mackenzie, I.R.; Boeve, B.F.; Boxer, A.L.; Baker, M.; Rutherford, N.J.; Nicholson, A.M.; Finch, N.A.; Flynn, H.; Adamson, J.; et al. Expanded GGGGCC hexanucleotide repeat in noncoding region of C9ORF72 causes chromosome 9p-linked FTD and ALS. Neuron 2011, 72, 245-256. [CrossRef]

7. Swinnen, B.; Robberecht, W. The phenotypic variability of amyotrophic lateral sclerosis. Nat. Rev. Neurol. 2014, 10, 661-670. [CrossRef]

8. Fan, J.; Dawson, T.M.; Dawson, V.L. Cell Death Mechanisms of Neurodegeneration. Adv. Neurobiol. 2017, 15, 403-425. [CrossRef]

9. Malik, A.R.; Willnow, T.E. Excitatory Amino Acid Transporters in Physiology and Disorders of the Central Nervous System. Int. J. Mol. Sci. 2019, 20, 5671. [CrossRef]

10. Bano, D.; Ankarcrona, M. Beyond the critical point: An overview of excitotoxicity, calcium overload and the downstream consequences. Neurosci. Lett. 2018, 663, 79-85. [CrossRef]

11. Singh, A.; Kukreti, R.; Saso, L.; Kukreti, S. Oxidative Stress: A Key Modulator in Neurodegenerative Diseases. Molecules 2019, 24, 1583. [CrossRef] [PubMed] 
12. Singh, E.; Devasahayam, G. Neurodegeneration by oxidative stress: A review on prospective use of small molecules for neuroprotection. Mol. Biol. Rep. 2020, 1-8. [CrossRef] [PubMed]

13. Yaribeygi, H.; Panahi, Y.; Javadi, B.; Sahebkar, A. The Underlying Role of Oxidative Stress in Neurodegeneration: A Mechanistic Review. CNS Neurol. Disord. Drug Targets 2018, 17, 207-215. [CrossRef] [PubMed]

14. Smith, R.L.; Soeters, M.R.; Wüst, R.; Houtkooper, R.H. Metabolic Flexibility as an Adaptation to Energy Resources and Requirements in Health and Disease. Endocr. Rev. 2018, 39, 489-517. [CrossRef]

15. Wu, W.; Zhao, D.; Shah, S.; Zhang, X.; Lai, M.; Yang, D.; Wu, X.; Guan, Z.; Li, J.; Zhao, H.; et al. OPA1 overexpression ameliorates mitochondrial cristae remodeling, mitochondrial dysfunction, and neuronal apoptosis in prion diseases. Cell Death Dis. 2019, 10, 710. [CrossRef]

16. Hickman, S.; Izzy, S.; Sen, P.; Morsett, L.; El Khoury, J. Microglia in neurodegeneration. Nat. Neurosci. 2018, 21, 1359-1369. [CrossRef]

17. Obál, I.; Nógrádi, B.; Meszlényi, V.; Patai, R.; Ricken, G.; Kovacs, G.G.; Tripolszki, K.; Széll, M.; Siklós, L.; Engelhardt, J.I. Experimental Motor Neuron Disease Induced in Mice with Long-Term Repeated Intraperitoneal Injections of Serum from ALS Patients. Int. J. Mol. Sci. 2019, 20, 2573. [CrossRef]

18. Voet, S.; Srinivasan, S.; Lamkanfi, M.; van Loo, G. Inflammasomes in neuroinflammatory and neurodegenerative diseases. EMBO Mol. Med. 2019, 11, e10248. [CrossRef]

19. Bezprozvanny, I. Calcium signaling and neurodegenerative diseases. Trends Mol. Med. 2009, 15, 89-100. [CrossRef]

20. Enders, M.; Heider, T.; Ludwig, A.; Kuerten, S. Strategies for Neuroprotection in Multiple Sclerosis and the Role of Calcium. Int. J. Mol. Sci. 2020, 21, 1663. [CrossRef]

21. Glaser, T.; Arnaud Sampaio, V.F.; Lameu, C.; Ulrich, H. Calcium signalling: A common target in neurological disorders and neurogenesis. Semin. Cell Dev. Biol. 2019, 95, 25-33. [CrossRef] [PubMed]

22. Pchitskaya, E.; Popugaeva, E.; Bezprozvanny, I. Calcium signaling and molecular mechanisms underlying neurodegenerative diseases. Cell Calcium 2018, 70, 87-94. [CrossRef] [PubMed]

23. Ureshino, R.P.; Erustes, A.G.; Bassani, T.B.; Wachilewski, P.; Guarache, G.C.; Nascimento, A.C.; Costa, A.J.; Smaili, S.S.; Pereira, G. The Interplay between $\mathrm{Ca}^{2+}$ Signaling Pathways and Neurodegeneration. Int. J. Mol. Sci. 2019, 20, 6004. [CrossRef] [PubMed]

24. Belsh, J.M.; Schiffman, P.L. The amyotrophic lateral sclerosis (ALS) patient perspective on misdiagnosis and its repercussions. J. Neurol. Sci. 1996, 139, 110-116. [CrossRef]

25. Patai, R.; Nógrádi, B.; Engelhardt, J.I.; Siklós, L. Calcium in the pathomechanism of amyotrophic lateral sclerosis-Taking center stage? Biochem. Biophys. Res. Commun. 2017, 483, 1031-1039. [CrossRef] [PubMed]

26. Siklós, L.; Engelhardt, J.; Harati, Y.; Smith, R.G.; Joó, F.; Appel, S.H. Ultrastructural evidence for altered calcium in motor nerve terminals in amyotropic lateral sclerosis. Ann. Neurol. 1996, 39, 203-216. [CrossRef] [PubMed]

27. Longinetti, E.; Fang, F. Epidemiology of amyotrophic lateral sclerosis: An update of recent literature. Curr. Opin. Neurol. 2019, 32, 771-776. [CrossRef] [PubMed]

28. Engelhardt, J.I.; Siklós, L.; Kömüves, L.; Smith, R.G.; Appel, S.H. Antibodies to calcium channels from ALS patients passively transferred to mice selectively increase intracellular calcium and induce ultrastructural changes in motoneurons. Synapse 1995, 20, 185-199. [CrossRef]

29. Sattler, R.; Tymianski, M. Molecular mechanisms of calcium-dependent excitotoxicity. J. Mol. Med. 2000, 78, 3-13. [CrossRef]

30. Choi, D.W.; Maulucci-Gedde, M.; Kriegstein, A.R. Glutamate neurotoxicity in cortical cell culture. J. Neurosci. 1987, 7, 357-368. [CrossRef]

31. Choi, D.W. Glutamate neurotoxicity and diseases of the nervous system. Neuron 1988, 1, 623-634. [CrossRef]

32. Choi, D.W. Glutamate neurotoxicity in cortical cell culture is calcium dependent. Neurosci. Lett. 1985, 58, 293-297. [CrossRef]

33. Arundine, M.; Tymianski, M. Molecular mechanisms of calcium-dependent neurodegeneration in excitotoxicity. Cell Calcium 2003, 34, 325-337. [CrossRef]

34. Alvarez, J.; Alvarez-Illera, P.; García-Casas, P.; Fonteriz, R.I.; Montero, M. The Role of $\mathrm{Ca}^{2+}$ Signaling in Aging and Neurodegeneration: Insights from Caenorhabditis elegans Models. Cells 2020, 9, 204. [CrossRef]

35. Berridge, M.J. Calcium hypothesis of Alzheimer's disease. Pflugers Archiv 2010, 459, 441-449. [CrossRef] 
36. Betzer, C.; Jensen, P.H. Reduced Cytosolic Calcium as an Early Decisive Cellular State in Parkinson's Disease and Synucleinopathies. Front. Neurosci. 2018, 12, 819. [CrossRef]

37. Grosskreutz, J.; Van Den Bosch, L.; Keller, B.U. Calcium dysregulation in amyotrophic lateral sclerosis. Cell Calcium 2010, 47, 165-174. [CrossRef]

38. Wang, X.; Zheng, W. $\mathrm{Ca}^{2+}$ homeostasis dysregulation in Alzheimer's disease: A focus on plasma membrane and cell organelles. FASEB J. 2019, 33, 6697-6712. [CrossRef]

39. von Lewinski, F.; Fuchs, J.; Vanselow, B.K.; Keller, B.U. Low $\mathrm{Ca}^{2+}$ buffering in hypoglossal motoneurons of mutant SOD1 (G93A) mice. Neurosci. Lett. 2008, 445, 224-228. [CrossRef]

40. von Lewinski, F.; Keller, B.U. $\mathrm{Ca}^{2+}$, mitochondria and selective motoneuron vulnerability: Implications for ALS. Trends Neurosci. 2005, 28, 494-500. [CrossRef]

41. May, C.; Nordhoff, E.; Casjens, S.; Turewicz, M.; Eisenacher, M.; Gold, R.; Brüning, T.; Pesch, B.; Stephan, C.; Woitalla, D.; et al. Highly immunoreactive IgG antibodies directed against a set of twenty human proteins in the sera of patients with amyotrophic lateral sclerosis identified by protein array. PLOS ONE 2014, 9, e89596. [CrossRef] [PubMed]

42. Pullen, A.H.; Humphreys, P. Ultrastructural analysis of spinal motoneurones from mice treated with IgG from ALS patients, healthy individuals, or disease controls. J. Neurol. Sci. 2000, 180, 35-45. [CrossRef]

43. Pullen, A.H.; Demestre, M.; Howard, R.S.; Orrell, R.W. Passive transfer of purified IgG from patients with amyotrophic lateral sclerosis to mice results in degeneration of motor neurons accompanied by $\mathrm{Ca}^{2+}$ enhancement. Acta Neuropathol. 2004, 107, 35-46. [CrossRef] [PubMed]

44. Demestre, M.; Pullen, A.; Orrell, R.W.; Orth, M. ALS-IgG-induced selective motor neurone apoptosis in rat mixed primary spinal cord cultures. J. Neurochem. 2005, 94, 268-275. [CrossRef] [PubMed]

45. Smith, R.G.; Hamilton, S.; Hofmann, F.; Schneider, T.; Nastainczyk, W.; Birnbaumer, L.; Stefani, E.; Appel, S.H. Serum antibodies to L-type calcium channels in patients with amyotrophic lateral sclerosis. N. Engl. J. Med. 1992, 327, 1721-1728. [CrossRef] [PubMed]

46. Delbono, O.; García, J.; Appel, S.H.; Stefani, E. IgG from amyotrophic lateral sclerosis affects tubular calcium channels of skeletal muscle. Am. J. Physiol. 1991, 260, C1347-C1351. [CrossRef]

47. Magnelli, V.; Sawada, T.; Delbono, O.; Smith, R.G.; Appel, S.H.; Stefani, E. The action of amyotrophic lateral sclerosis immunoglobulins on mammalian single skeletal muscle $\mathrm{Ca}^{2+}$ channels. J. Physiol. 1993, 461, $103-118$. [CrossRef]

48. Mosier, D.R.; Baldelli, P.; Delbono, O.; Smith, R.G.; Alexianu, S.E.; Appel, S.H.; Stefani, E. Amyotrophic lateral sclerosis immunoglobulins increase $\mathrm{Ca}^{2+}$ currents in a motoneuron cell line. Ann. Neurol. 1995, 37, 102-109. [CrossRef]

49. Llinás, R.; Sugimori, M.; Cherksey, B.D.; Smith, R.G.; Delbono, O.; Stefani, E.; Appel, S. IgG from amyotrophic lateral sclerosis patients increases current through P-type calcium channels in mammalian cerebellar Purkinje cells and in isolated channel protein in lipid bilayer. Proc. Natl. Acad. Sci. USA 1993, 90, 11743-11747. [CrossRef]

50. Engelhardt, J.I.; Siklos, L.; Appel, S.H. Altered calcium homeostasis and ultrastructure in motoneurons of mice caused by passively transferred anti-motoneuronal IgG. J. Neuropathol. Exp. Neurol. 1997, 56, 21-39. [CrossRef]

51. La Bella, V.; Goodman, J.C.; Appel, S.H. Increased CSF glutamate following injection of ALS immunoglobulins. Neurology 1997, 48, 1270-1272. [CrossRef] [PubMed]

52. Obál, I.; Klausz, G.; Mándi, Y.; Deli, M.; Siklós, L.; Engelhardt, J.I. Intraperitoneally administered IgG from patients with amyotrophic lateral sclerosis or from an immune-mediated goat model increase the levels of TNF- $\alpha$, IL-6, and IL-10 in the spinal cord and serum of mice. J. Neuroinflamm. 2016, 13, 121. [CrossRef] [PubMed]

53. Milošević, M.; Milićević, K.; Božić, I.; Lavrnja, I.; Stevanović, I.; Bijelić, D.; Dubaić, M.; Zivković, I.; Stević, Z.; Giniatullin, R.; et al. Immunoglobulins G from Sera of Amyotrophic Lateral Sclerosis Patients Induce Oxidative Stress and Upregulation of Antioxidative System in BV-2 Microglial Cell Line. Front. Immunol. 2017, 8, 1619. [CrossRef] [PubMed]

54. Milošević, M.; Stenovec, M.; Kreft, M.; Petrušić, V.; Stević, Z.; Trkov, S.; Andjus, P.R.; Zorec, R. Immunoglobulins $\mathrm{G}$ from patients with sporadic amyotrophic lateral sclerosis affects cytosolic $\mathrm{Ca}^{2+}$ homeostasis in cultured rat astrocytes. Cell Calcium 2013, 54, 17-25. [CrossRef] [PubMed] 
55. Brooks, B.R.; Miller, R.G.; Swash, M.; Munsat, T.L.; World Federation of Neurology Research Group on Motor Neuron Diseases. El Escorial revisited: Revised criteria for the diagnosis of amyotrophic lateral sclerosis. Amyotroph. Lateral Scler. Other Motor Neuron Disord. 2000, 1, 293-299. [CrossRef]

56. Appel, S.H.; Engelhardt, J.I.; García, J.; Stefani, E. Immunoglobulins from animal models of motor neuron disease and from human amyotrophic lateral sclerosis patients passively transfer physiological abnormalities to the neuromuscular junction. Proc. Natl. Acad. Sci. USA 1991, 88, 647-651. [CrossRef]

57. Mosier, D.R.; Siklós, L.; Appel, S.H. Resistance of extraocular motoneuron terminals to effects of amyotrophic lateral sclerosis sera. Neurology 2000, 54, 252-255. [CrossRef]

58. Balendra, R.; Isaacs, A.M. C9orf72-mediated ALS and FTD: Multiple pathways to disease. Nat. Rev. Neurol. 2018, 14, 544-558. [CrossRef]

59. Lall, D.; Baloh, R.H. Microglia and C9orf72 in neuroinflammation and ALS and frontotemporal dementia. J. Clin. Investig. 2017, 127, 3250-3258. [CrossRef]

60. Sudria-Lopez, E.; Koppers, M.; de Wit, M.; van der Meer, C.; Westeneng, H.J.; Zundel, C.A.; Youssef, S.A.; Harkema, L.; de Bruin, A.; Veldink, J.H.; et al. Full ablation of C9orf72 in mice causes immune system-related pathology and neoplastic events but no motor neuron defects. Acta Neuropathol. 2016, 132, 145-147. [CrossRef]

61. Siklós, L.; Engelhardt, J.I.; Alexianu, M.E.; Gurney, M.E.; Siddique, T.; Appel, S.H. Intracellular calcium parallels motoneuron degeneration in SOD-1 mutant mice. J. Neuropathol. Exp. Neurol. 1998, 57, 571-587. [CrossRef] [PubMed]

62. Lips, M.B.; Keller, B.U. Endogenous calcium buffering in motoneurones of the nucleus hypoglossus from mouse. J. Physiol. 1998, 511, 105-117. [CrossRef] [PubMed]

63. Palecek, J.; Lips, M.B.; Keller, B.U. Calcium dynamics and buffering in motoneurones of the mouse spinal cord. J. Physiol. 1999, 520, 485-502. [CrossRef] [PubMed]

64. Vanselow, B.K.; Keller, B.U. Calcium dynamics and buffering in oculomotor neurones from mouse that are particularly resistant during amyotrophic lateral sclerosis (ALS)-related motoneurone disease. J. Physiol. 2000, 525, 433-445. [CrossRef] [PubMed]

65. Beers, D.R.; Ho, B.K.; Siklós, L.; Alexianu, M.E.; Mosier, D.R.; Mohamed, A.H.; Otsuka, Y.; Kozovska, M.E.; McAlhany, R.E.; Smith, R.G.; et al. Parvalbumin overexpression alters immune-mediated increases in intracellular calcium, and delays disease onset in a transgenic model of familial amyotrophic lateral sclerosis. J. Neurochem. 2001, 79, 499-509. [CrossRef]

66. Van Den Bosch, L.; Van Damme, P.; Bogaert, E.; Robberecht, W. The role of excitotoxicity in the pathogenesis of amyotrophic lateral sclerosis. Biochim. Biophys. Acta 2006, 1762, 1068-1082. [CrossRef]

67. Tortarolo, M.; Grignaschi, G.; Calvaresi, N.; Zennaro, E.; Spaltro, G.; Colovic, M.; Fracasso, C.; Guiso, G.; Elger, B.; Schneider, H.; et al. Glutamate AMPA receptors change in motor neurons of SOD1G93A transgenic mice and their inhibition by a noncompetitive antagonist ameliorates the progression of amytrophic lateral sclerosis-like disease. J. Neurosci. Res. 2006, 83, 134-146. [CrossRef]

68. Paizs, M.; Tortarolo, M.; Bendotti, C.; Engelhardt, J.I.; Siklós, L. Talampanel reduces the level of motoneuronal calcium in transgenic mutant SOD1 mice only if applied presymptomatically. Amyotroph. Lateral Scler. Other Motor Neuron Disord. 2011, 12, 340-344. [CrossRef]

69. Tripolszki, K.; Danis, J.; Padhi, A.K.; Gomes, J.; Bozó, R.; Nagy, Z.F.; Nagy, D.; Klivényi, P.; Engelhardt, J.I.; Széll, M. Angiogenin mutations in Hungarian patients with amyotrophic lateral sclerosis: Clinical, genetic, computational, and functional analyses. Brain Behav. 2019, 9, e01293. [CrossRef]

70. Costa, J.; Swash, M.; de Carvalho, M. Awaji criteria for the diagnosis of amyotrophic lateral sclerosis: A systematic review. Arch. Neurol. 2012, 69, 1410-1416. [CrossRef]

71. Cedarbaum, J.M.; Stambler, N.; Malta, E.; Fuller, C.; Hilt, D.; Thurmond, B.; Nakanishi, A. The ALSFRS-R: A revised ALS functional rating scale that incorporates assessments of respiratory function. BDNF ALS Study Group (Phase III). J. Neurol. Sci. 1999, 169, 13-21. [CrossRef]

72. Borgers, M.; De Brabander, M.; Van Reempts, J.; Awouters, F.; Jacob, W.A. Intranuclear microtubules in lung mast cells of guinea pigs in anaphylactic shock. Lab. Investig. 1977, 37, 1-8. [CrossRef] [PubMed]

73. Borgers, M. The role of calcium in the toxicity of the myocardium. Histochem. J. 1981, 13, 839-848. [CrossRef] [PubMed]

74. Adalbert, R.; Engelhardt, J.I.; Siklós, L. DL-Homocysteic acid application disrupts calcium homeostasis and induces degeneration of spinal motor neurons in vivo. Acta Neuropathol. 2002, 103, 428-436. [CrossRef] 
75. Obál, I.; Engelhardt, J.I.; Siklós, L. Axotomy induces contrasting changes in calcium and calcium-binding proteins in oculomotor and hypoglossal nuclei of Balb/c mice. J. Comp. Neurol. 2006, 499, 17-32. [CrossRef]

76. Paizs, M.; Engelhardt, J.I.; Katarova, Z.; Siklós, L. Hypoglossal motor neurons display a reduced calcium increase after axotomy in mice with upregulated parvalbumin. J. Comp. Neurol. 2010, 518, 1946-1961. [CrossRef]

77. Patai, R.; Paizs, M.; Tortarolo, M.; Bendotti, C.; Obál, I.; Engelhardt, J.I.; Siklós, L. Presymptomatically applied AMPA receptor antagonist prevents calcium increase in vulnerable type of motor axon terminals of mice modeling amyotrophic lateral sclerosis. Biochim. Biophys. Acta Mol. Basis Dis. 2017, 1863, 1739-1748. [CrossRef]

78. Siklós, L.; Kuhnt, U.; Párducz, A.; Szerdahelyi, P. Intracellular calcium redistribution accompanies changes in total tissue $\mathrm{Na}^{+}, \mathrm{K}^{+}$and water during the first two hours of in vitro incubation of hippocampal slices. Neuroscience 1997, 79, 1013-1022. [CrossRef]

79. Maxwell, M.H. Two rapid and simple methods used for the removal of resins from 1.0 micron thick epoxy sections. J. Microsc. 1978, 112, 253-255. [CrossRef]

80. Richardson, K.C.; Jarett, L.; Finke, E.H. Embedding in epoxy resins for ultrathin sectioning in electron microscopy. Stain Technol. 1960, 35, 313-323. [CrossRef]

81. Cruz-Orive, L.M.; Weibel, E.R. Sampling designs for stereology. J. Microsc. 1981, 122, 235-257. [CrossRef] [PubMed]

82. Hayat, M.A. Principles and Techniques of Electron Microscopy: Biological Applications, 4th ed.; Cambridge University Press: Cambridge, UK, 2000.

83. Reynolds, E.S. The use of lead citrate at high $\mathrm{pH}$ as an electron-opaque stain in electron microscopy. J. Cell Biol. 1963, 17, 208-212. [CrossRef] [PubMed]

84. Mayhew, T.M. A review of recent advances in stereology for quantifying neural structure. J. Neurocytol. 1992, 21, 313-328. [CrossRef] [PubMed]

85. Weibel, E.R. Stereological Methods Vol. 1. Practical Methods for Biological Morphometry; Academic Press: London, UK; New York, NY, USA; Toronto, ON, USA; Sydney, Australia; San Francisco, CA, USA, 1979.

86. Domoki, F.; Bari, F.; Nagy, K.; Busija, D.W.; Siklós, L. Diazoxide prevents mitochondrial swelling and Ca ${ }^{2+}$ accumulation in CA1 pyramidal cells after cerebral ischemia in newborn pigs. Brain Res. 2004, 1019, 97-104. [CrossRef]

(C) 2020 by the authors. Licensee MDPI, Basel, Switzerland. This article is an open access article distributed under the terms and conditions of the Creative Commons Attribution (CC BY) license (http://creativecommons.org/licenses/by/4.0/). 